Institute gave birth to the first continuous flow cell separator. ${ }^{5}$

Initially, cell separators were used to collect granulocytes and platelets from single donors for supportive treatment for immunosuppressed patients with cancer. In the mid-1970s plasma exchange began to be used as a therapeutic modality, and there were soon reports of its dramatic effectiveness in Goodpasture's disease and in myasthenia gravis. ${ }^{67}$ For the next few years plasma exchange was tried in over 90 different diseases-almost any disorder with an immune component. Research studies using controlled clinical trials have now defined some of the disease categories in which therapeutic plasma exchange is of proved benefit. ${ }^{8}$

The next development came in the early 1980s, when Britain decided to attempt to achieve national self sufficiency in blood and blood products by using voluntary unpaid donors. The demand for plasma outstripped the demand for red cells, and the shortfall was met by the introduction of automated apheresis machine donation programmes. Transfusion services are now-at least potentially-flexible enough to respond to whatever demands are placed on them for plasma, platelets, or red cells, through use of the multicomponent donor apheresis collection machines currently undergoing clinical trials. Specific protein donation is still being developed.

Advances are also being made in therapeutic apheresis. Secondary cascade filtration and various adsorption columns (some using monoclonal technology) are being investigated in the hope of removing the causative agent of the disease rather than the relatively crude "remove all" approach of plasma exchange. Equally interesting developments are occurring in leukapheresis. The range of cells that can now be collected include killer cells, macrophage-monocyte cells, and myeloid stem cells. These developments began with the advent of interleukin 2 and the generation and retransfusion of lymphocyte activated killer cells in the treatment of patients with cancer. ${ }^{9}$ Next came extracorporeal photoactivation for the immune modulation of mononuclear cells in the successful management of cutaneous $T$ cell lymphoma. This technique may possibly also be useful in certain other aberrant $T$ cell disorders, including graft $v$ host disease. ${ }^{9}$ The development of effective monoclonal haemopoietic cytokines has made it possible to collect peripheral stem cells for bone marrow grafting - and this may eventually prove a better method of achieving marrow engraftment. The use of separation procedures such as electrophoresis and cell adhesion may further improve the efficiency, speed, and specificity of cell separation and collection.

The most exciting development to date is the management of immune deficiency syndromes with gene modified peripheral blood mononuclear cells. ${ }^{10}$ The interdisciplinary cooperation that these innovative developments require may need to come from transfusion medicine, where expertise in cell separation and purification technology, cell component support, development and use of recombinant human growth factors, and transplant immunology are all needed to provide the necessary catalytic environment for dramatic developments in haemapheresis for the 1990s.

E ANGELA ROBINSON Director

Yorkshire Regional Blood Transfusion Service, Leeds LS15 7TW

1 Abel JJ, Rowntree LG, Tumer BB. Plasma removal with return of corpuscles (plasmapheresis). $f$ Pharmacol Exp Ther 1914;5:625-41.

2 Co Tui, Bartter FC, Wright AM, Holt RD. Red cell reinfusion and the frequency of plasma donations. FAMA 1944;124:331.

3 Adams WS, Bland WH, Bassetts H. A method of human plasmapheresis. Proc Soc Exp Biol Med 1952;80:371-7.

4 Pool JG. Cryoprecipitated factor VIII concentrate. Bibleotheca Haematologica 1970;34:23.

5 Friereich EJ, Judson G, Levin RH. Separation and collection of leukocytes. Cancer Res 1965;25:1516-20.

6 Lockwood CM, Rees AJ, Pearson TA, Evans DJ, Peters DK, Wilson CB. Immunosuppression and plasma exchange in the treatment of Goodpasture's syndrome. Lancet 1976;ii:711-5.

7 Pinching AJ, Peters DK, Newsom Davies J. Remission of myasthenia gravis following plasma exchange. Lancet 1976;ii:1373-6.

8 Urbaniak SJ, Robinson EA. Therapeutic apheresis. In: Contreras M, ed. ABC of transfusion. London: BMJ Publishing Group, 1992:53-6.

9 Rosenberg SA, Lotze MT, Muul LM, Leitman S, Chang AE, Ettinghausen SE, et al. Observations on the systemic administration of autologous lymphokine-activated killer cells and recombinan interleukin-2 to patients with metastatic cancer. N Engl f Med 1985;23:1485-92.

10 Edelson RL. Photopheresis: a clinically relevant immunobiologic response modifier. Ann NY Acad Sci 1991;636:154-64.

\title{
Leukaemia: a genetic disorder of haemopoietic cells
}

\section{Understanding the mechanism can help management and may one day improve treatment}

The change of a cell from normal to malignant is generally accepted to be a multistep process. Interestingly, the first evidence for this came not from high tech laboratory research but from an imaginative use of epidemiology when it was noted that the overall frequency of tumours as a function of age fits a straight line on a log-log plot, ${ }^{1}$ suggesting to the mathematically minded that the probability of developing a tumour behaves like the result of a cumulative succession of random events.

The best candidate for a random event that can change permanently the behaviour of a cell and its progeny is a somatic mutation; the progeny of the cell in which the mutation has taken place is a mutated clone. Again we do not need sophisticated tools to visualise these processes. A pigmented naevus is a visible clone of an epidermal cell that makes more melanin than the cells around it; freckles accumulate on our skin as we get older and give us a tangible impression of the rate of somatic mutation. If we extrapolate from these considerations to the pathogenesis of leukaemia then the notion that this consists of one or more somatic mutations arising in a haemopoietic cell seems the only sensible model. But what evidence do we have that it is true?

If we look back at textbooks of some 50 years ago we find different "theories" of leukaemogenesis": the viral theory, corroborated by animal experiments; the physical agents theory, documented by the victims of leukaemia in Hiroshima; and the chemical agents theory, supported by the development of leukaemia after exposure to benzene or cytotoxic agents. Today we know that retroviruses can integrate into the host cell genome and that radiation and alkylating agents are mutagens. Thus the various theories are not in conflict: on the contrary, the somatic mutations model reconciles them all.

Molecular analysis of leukaemic cells has allowed us to identify some of these somatic mutations. The first example came from the study of Burkitt's lymphoma and from the related form of acute lymphoblastic leukaemia called L3. Here the gene c-myc, encoding a nuclear DNA binding protein, is brought by a $t(8 ; 14)$ chromosomal translocation to be juxtaposed to an immunoglobulin gene. Subsequently, another well known translocation, the $t(9 ; 22)$, giving rise to the Philadelphia chromosome of chronic myeloid leukaemia, proved to be the first example of what we now call a chimeric 
Leukaemias with underlying somatic genetic change

\begin{tabular}{|c|c|c|c|}
\hline Leukaemia & $\begin{array}{c}\text { Chromosomal } \\
\text { event }\end{array}$ & Genes involved & Possible mechanisms \\
\hline \multicolumn{4}{|c|}{ Group 1-fusion genes } \\
\hline $\begin{array}{l}\text { Chronic myeloid } \\
\text { leukaemia }\end{array}$ & $\mathfrak{t}(9 ; 22)(q 34 ; q 11)$ & BCR-ABL & Tyrosine kinase activity \\
\hline $\begin{array}{l}\text { Acute myeloid } \\
\text { leukaemia } M 3^{-9}\end{array}$ & $t(15 ; 17)(q 22 ; q 21)$ & PML-RAR $\alpha$ & Block of differentiation \\
\hline $\begin{array}{l}\text { Acute myeloid } \\
\text { leukaemia } M 2^{10-13}\end{array}$ & $\mathrm{t}(8 ; 21)(\mathrm{q} 22 ; \mathrm{q} 22)$ & AML1-ETO & $\begin{array}{l}\text { Modified transcription } \\
\text { factor }\end{array}$ \\
\hline \multicolumn{4}{|c|}{ Group 2-position effects } \\
\hline $\begin{array}{l}\text { Acute lymphoblastic } \\
\text { leukaemia L314 }\end{array}$ & $\mathrm{t}(8 ; 14)(\mathrm{q} 24 ; \mathrm{q} 32)$ & c-MYC-IgH & $\begin{array}{l}\text { Activation of proto- } \\
\text { oncogene by } \\
\text { proximity to } \\
\text { immunoglobulin } \\
\text { gene enhancer }\end{array}$ \\
\hline $\begin{array}{l}\text { Follicular } \\
\text { lymphoma }^{1516}\end{array}$ & $t(14 ; 18)(q 32 ; q 21)$ & BCL2-IgH & Failure of apoptosis? \\
\hline $\begin{array}{l}\text { T acute lymphoblasti } \\
\text { leukaemia }^{17} 18\end{array}$ & $t(11 ; 14)(p 15 ; q 11)$ & TCR-RHOMBOTIN1 & \\
\hline
\end{tabular}

gene, where two genes have fused to yield an abnormal protein. Since then similar examples have turned up in various leukaemias, and two groups are clearly emerging; the two examples of chronic myeloid leukaemia and acute lymphoblastic leukaemia L3 can be regarded as prototypes of these two groups (table).

The genes which, when deranged, help to cause neoplastic change are called oncogenes. It is important to remember that when not deranged they are essential normal cellular genes. Thus, while much has been published on their increased or decreased expression, it is often impossible to know whether such changes are the cause or the effect of leukaemia. Only when we find a mutational change in one such gene can we presume that it is causally implicated in the leukaemogenetic process.

At first sight these findings of a single chromosomal event causing leukaemia do not fit well with the concept of stepwise leukaemogenesis. However, clinical observations suggest how they might fit. The transition from monoclonal gammopathy of uncertain significance to multiple myeloma, or from chronic myeloid leukaemia to blast transformation, is seen only too often; and the nosological definition of myelodysplastic syndromes has its origin in the notion that these syndromes are preleukaemic conditions. Thus we can visualise two (not mutually exclusive) ways in which a condition can be preleukaemic.

On the one hand, because mutations are random events of low probability, the larger the target population the greater the risk that a leukaemogenic mutation may take place. Burkitt's lymphoma may be more frequent in endemic areas because children in these areas have larger numbers of proliferating B cells, owing to early infection with the EpsteinBarr virus or other infections. On the other hand, a mutational event such as the $t(9 ; 22)$ in chronic myeloid leukaemia may cause a clonal expansion of the target population while being at the same time the first step in leukaemic transformation. Thus chronic myeloid leukaemia is a myeloproliferative disorder and at the same time a preleukaemic condition, of which blast transformation is the fully fledged leukaemic outcome.

Finally, in some cases a single mutational event may be so powerful that it transforms a normal cell into a leukaemic cell in one step. The complete association of the $t(15 ; 17)$ translocation with acute myeloid leukaemia M3 suggests that this is what happens in this type of leukaemia. ${ }^{19}$ The extreme case of leukaemogenesis taking place in $\mathrm{n}$ steps is that $\mathrm{n}=1$.

Do these concepts help us in managing leukaemia? Treatment of these disorders is still largely empirical, and we must continue to scrutinise actuarial curves of disease free survival after chemotherapy alone or after chemotherapy supplemented with bone marrow transplantation. Nevertheless, some of the mutations and translocations represent a new type of marker because they are causally associated with leukaemia. Thus they are invaluable not only in our understanding of leukaemia but also in the follow up of patients. Already it has been shown that their detection by the polymerase chain reaction is the most accurate prediction of cure in some cases. ${ }^{20}$ Whether they can be also made the target of new approaches to treatment remains to be seen.

LUCIO LUZZATTO

Professor of haematology PIER PAOLO PANDOLFI

Research fellow

Royal Postgraduate Medical School,

Haematology Department,

Hammersmith Hospital,

London W12 0NN

1 Peto R. Cancer epidemiology and multistage models. In: Hiatt HH, Watson JD, Winsten JA, eds. Origins of human cancer. Cold Spring Harbor, New York: Cold Spring Harbor Laboratory, 1977:1403-28.

2 Levi G. Istologia. 3rd ed. Turin: Unione Tipografica Editrice Torinese, 1946.

3 De Klein A, van Kessel AG, Grosveld G, Bartram CR, Hagemeijer A, Bootsma D, et al. A cellular oncogene is translocated to the Philadelphia chromosome in chronic myelocytic leukemia. Nature 1982;300:765-7.

4 Heisterkamp N, Groffen J, Stephenson JR, Spurr NK, Goodfellow PN, Solomon E, et al Chromosomal translocation of human cellular homologues of two viral oncogenes. Nature Chromosomal tran

5 Shtivelman E, Lifshitz B, Gale RB, Canaani E. Fused transcript of abl and ber genes in chronic myelogenous leukemia. Nature 1985;315:550-4.

6 Longo L, Pandolfi PP, Biondi A, Rambaldi A, Mencarelli A, Lo Coco F, et al. Rearrangements and aberrant expression of the retinoic acid receptor $\alpha$ gene in acute promyelocytic leukemias. $f$ Exp Med 1990;172:1571-5.

7 Borrow J, Goddard AD, Sheer D, Solomon E. Molecular analysis of acute promyelocytic leukemia breakpoint cluster region on chromosome 17. Science 1990;249:1577-80.

8 deThe' H, Chomienne C, Lanotte M, Degos L, Dejean A. The t $(15 ; 17)$ translocation of acute promyelocytic leukaemia fuses the retinoic acid receptor $\alpha$ gene to a novel transcribed locus. Nature 1990;347:558-61.

9 Pandolfi PP, Grignani FR, Alcalay M, Mencarelli A, Biondi A, Lo Coco F, et al. Structure and origin of the acute promyelocytic leukemia my/RAR $\alpha$ CDNA and characterization of its retinoidbinding and transactivation properties. Oncogene 1991;8:1285-92.

10 Gao J, Erickson P, Gardiner K, LeBeau MM, Diaz MO, Patterson D, et al. Isolation of a yeast artificial chromosome spanning the $8 ; 21$ translocation breakpoint, $t(8 ; 21)(\mathrm{q} 22 ; \mathrm{q} ; 22.3)$ in acute artificial chromosome spanning the 8;21 translocation breakpoin
myelogenous leukemia. Proc Natl Acad Sci USA 1991;88:4882-6.

11 Shimizu $\mathrm{K}$, Ichikawa $\mathrm{H}$, Miyoshi $\mathrm{H}$, Ohki $M$, Kobayashi $\mathrm{H}$, Maseki N, et al. Molecular assignmen of a translocation breakpoint in acute myeloid leukaemia with $t(8 ; 21)$. Genes Chromosomes and Cancer 1991;3:163-7.

12 Tighe JE, Daga A, Calabi F. Translocation breakpoints are clustered on both chromosome 8 and chromosome 21 in the $t(8 ; 21)$ of acute myeloid leukemia. Blood 1993;81:592-6.

13 Nucifora G, Birn DJ, Erickson P, Gao J, LeBeau MM, Drabkin HA, et al. Detection of DNA rearrangements in the AML1 and ETO loci and of an AML/ETO fusion mRNA in patients with $t(8 ; 21)$ acute myeloid leukemia. Blood 1993;81:883-8.

14 Gelmann EP, Psallidopoulos CM, Papas TS, Dalla-Favera R. Identification of reciprocal translocation sites within the c-myc oncogene and immunoglobulin $\mu$ locus in a Burkit lymphoma. Nature 1983;306:799-803.

15 Cleary $\mathrm{ML}$, Sklar J. Nucleotide sequence of a $t(14 ; 18)$ chromosomal breakpoint in follicular lymphoma and demonstration of a breakpoint cluster region near a transcriptionally active locus on chromosome 18. Proc Natl Acad Sci USA 1985;82:7439-43.

16 Vaux DL, Cory S, Adams JM. Bcl-2 gene promotes haemopoietic cell survival and cooperates with c-myc to immortalize pre-B cells. Nature 1988;335:440-2.

17 McGuire EA, Hockett RD, Pollock KM, Bartholdi MF, O'Brien SO, Korsmeyer SJ. The $t(11 ; 14)(p 15 ; q 11)$ in a T-cell acute lymphoblastic leukemia cell line activates multiple transcripts, including Ttg-1, a gene encoding a potential zinc finger protein. Mol Cell Biol 1989;9:2124-32.

18 Boehm T, Foroni L, Kaneko Y, Perutz MF, Rabbitts TH. The rhombotin family of cystein-rich LIM-domain oncogenes: distinct members are involved in T-cell translocations to human chromosomes $11 \mathrm{p} 15$ and 11p13. Proc Natl Acad Sci USA 1991;88:4367-72.

19 Lo Coco F, Diverio D, Adamo F, Avvisati G, Alimena G, Nanni M, et al. PML/RARo rearrangement in acute promyelocytic leukaemias apparently lacking the $t(15 ; 17)$ translocation. Eur f Haematol 1992;48:173-6.

20 Lo Coco F, Diverio D, Pandolfi PP, Biondi A, Rossi V, Avvisati G, et al. Molecular evaluation of residual disease as a predictor of relapse in acute promyelocytic leukaemia. Lancet 1992;340:1437-8. 